\title{
The ecological role of ponds in a changing world
}

\author{
Régis Céréghino - Dani Boix • \\ Henry-Michel Cauchie • \\ Koen Martens • Beat Oertli
}

Received: 14 October 2013/Accepted: 19 October 2013/Published online: 7 November 2013

(C) Springer Science+Business Media Dordrecht 2013

\begin{abstract}
The fifth conference of the European Pond Conservation Network (Luxembourg, June 2012) brought together researchers, environmental managers, and other stakeholders with the aim to share stateof-the-art knowledge on the ecology, management, and conservation of ponds in the context of the many challenges facing the wider water environment. Although well-known ecological patterns apply to most ponds in Europe and elsewhere, recent data highlight that part of the environmental variables governing pond biodiversity remain specific to climatic/biogeographic regions and to elevation ranges, suggesting that, in addition to common practice, management plans should include range-specific
\end{abstract}

Guest editors: R. Céréghino, D. Boix, H.-M. Cauchie,

K. Martens \& B. Oertli / Understanding the role of ponds in a changing world

R. Céréghino $(\square)$

INP, UPS EcoLab (Laboratoire Ecologie Fonctionnelle et

Environnement), Université de Toulouse,

31062 Toulouse, France

e-mail: regis.cereghino@univ-tlse3.fr

R. Céréghino

CNRS, EcoLab (UMR-CNRS 5245), 118 Route de

Narbonne, 31062 Toulouse, France

D. Boix

Institut d'Ecologia Aquàtica, Universitat de Girona

(UdG), Girona, Campus Montilivi, 17071 Girona,

Catalonia, Spain measures. Beyond the contribution of individual ponds to the aquatic and terrestrial life, connected networks of ponds are vital in the provision of new climate space as a response to global climate change, by allowing the observed northward and/or upward movements of species. In terms of services, ponds offer sustainable solutions to key issues of water management and climate change such as nutrient retention, rainfall interception, or carbon sequestration. While the ecological role of ponds is now wellestablished, authoritative research-based advice remains needed to inform future direction in the conservation of small water bodies and to further bridge the gap between science and practice.

Keywords Biological diversity · Conservation · Climate change $\cdot$ Ecosystem services .

Freshwater ecology

\section{H.-M. Cauchie}

Centre de Recherche Public Gabriel Lippman, 41, Rue du Brill, 4422 Belvaux, Luxembourg

K. Martens

Royal Belgian Institute of Natural Sciences, Vautierstraat 29, 1000 Brussels, Belgium

B. Oertli

University of Applied Sciences Western Switzerland, Hepia Lullier, 150 Route de Presinge, 1254 Jussy-Geneva, Switzerland 


\section{Introduction}

Worldwide, ponds of both natural of human origin occur in all biogeographical regions, from desert to tundra pools in the Arctic Circle. Estimates suggest that there are $277,400,000$ ponds less than 1 hectare in size, plus $24,120,000$ water bodies ranging from 1 to 10 ha, thus representing over $90 \%$ of the global 304 millions standing waterbodies, or $30 \%$ of global standing water by surface area (Downing et al., 2006). A literature search among the peer-reviewed, scientific journals suggests that the number of papers on pond biodiversity published per year has tripled over the past decade (source: Thomson Reuters' Web of Knowledge ${ }^{\mathrm{SM}}$, August 2013). In the context of changing world (climate, landscapes, water uses, and environmental policies), we can now ascertain that ponds are biodiversity hotspots both in terms of species composition and biological traits, and have a significant role to play in the provision of ecosystem services (EPCN, 2008). In addition, available data point toward the idea that artificial, "man-made" ponds are not fundamentally ecologically different from the "natural" ones (de Marco et al., 2013). Biological diversity of man-made ponds in farmed and urban landscapes was unambiguously related to wellknown ecological patterns (regionalization of assemblages, species-area effect, and successional patterns; Declerck et al., 2006; Céréghino et al., 2008b; Ruhí et al., 2012) rather than to particular uses (Scher \& Thiéry, 2005; Ruggiero et al., 2008; Le Viol et al., 2009). In other words, with their small catchments, ponds of all origins are a practical conservation solution waiting to happen.

Combining information collected at sites across Europe which represent a geographical distribution of biodiversity found in the Atlantic, Central, and Mediterranean regions, it becomes apparent that freshwater species show higher biogeographic turnover in composition and traits in ponds than in other extensive freshwater habitats (Céréghino et al., 2012). On a local to regional scale, we know that the value of ponds for freshwater diversity lies in the varied network of habitats that they provide (Davies et al., 2008), even in urban areas (Gaston et al., 2005; Vermonden et al., 2010). While pond biologists have focused on the aquatic biota, it is noteworthy that the interactions at the aquatic-terrestrial interface are numerous, and the high productivity of ponds is profitable to the terrestrial biocoenoses (Mozley, 1944; Baxter et al., 2005). Emerging adult insects are heavily preyed on by bats, birds, and spiders. Amphibians are preyed on by snakes, eagles, owls, ravens, buzzards, herons, wild boars, stoats, minks, martens, foxes, and badgers, while the water shrew (Neomys fodiens) comes directly to feed underwater on macroinvertebrate larvae.

In terms of services, ponds offer sustainable solutions to some of the key issues of water management and climate change. Ponds can remove diffuse pollutants from surface waters, including sediment, phosphorous, and nitrogen. For example, in the intensively farmed landscape of northern Germany, ponds strategically located to intercept water from drainage systems can significantly reduce the nutrient load of receiving waters through denitrification, sedimentation processes and uptake from wetland plants (Steidl et al., 2008). Moreover, while the purpose of such man-made ponds is related to water management (i.e., nutrient retention), biodiversity may benefit from their presence and heterogeneity (Becerra-Jurado et al., 2012; Herrmann, 2012). Strategically located pond networks have the potential to hold water back at source, recharge aquifers, and reduce the volumes of water generated before they become a problem. Modeling studies in the United Kingdom have shown that by installing $10,000 \mathrm{~m}^{3}$ of storage per $\mathrm{km}^{2}$, roughly equivalent to ten mediumsized ponds, it is possible to capture all of a typical heavy rainfall event from that $\mathrm{km}^{2}$, significantly reducing water loss (Quinn et al., 2007). Because of their huge number, farm ponds may globally sequester as much carbon as the oceans (Downing et al., 2008). A single $500 \mathrm{~m}^{2}$ pond could sequester yearly $1000 \mathrm{~kg}$ of carbon, i.e., as much as that produced by a car during the same time period. Such selected, striking examples support the case for the use of pond protection and/or creation to help ameliorate climate change and facilitate water resource management, and emphasize the importance of considering the pond resource as a whole rather than as individual sites.

More recently, ponds appeared as vital in the provision of new climate space as a response to global climate change (Rosset \& Oertli, 2011). Without connected networks of ponds, many amphibians and invertebrates, for example, will be unable to undertake the observed northward movement of species (Ott, 2001; Walther et al., 2002) (or upward movement in the mountains), further threatening species existence 
(Ilg \& Oertli, 2013). To enable the aquatic organisms associated with ponds to adapt to climate change, spatial land use planning from the European to local level needs to provide opportunities for these taxa to move through the landscape. Consequently, spatial planners are key stakeholders in the development of pond conservation. Spatial planning should encourage measures that enable the pond biota to adapt to climate change in particular by increasing connectivity, notably between the NATURA 2000 sites.

In this general context, continuing the series of European Pond Conservation Network conferences, the 5th EPCN meeting (Luxembourg, June 2012) brought together researchers, environmental managers, and other stakeholders with the aim to share stateof-the-art knowledge on the ecology, management, and conservation of ponds in the context of the many challenges facing the wider water environment. This special issue gathers some of the key information presented by international contributors, and provides an overview of current basic and applied issues on the ecological role of ponds as regards biological conservation, ecosystem services, and the mitigation of climate change effects on species.

\section{The 5th EPCN conference}

The keynote presentations, oral and poster contributions were distributed among 10 topics forming sessions that covered the multi-faceted aspects of relevant knowledge about ponds in the fields of socioeconomy, conservation and management of species, pond ecosystems, and pondscapes, functional and evolutionary ecology, and landscape ecology. In addition, three workshops were devoted to the practical conservation of ponds, pond policy within the EU Water Framework Directive, and ponds and local culture.

One-hundred and ten researchers and practitioners from 19 countries attended the conference. It is noteworthy that participants were more evenly distributed among represented countries than during the former 2008 and 2010 conferences and that contributors from countries outside Europe (the USA, Israel, Uruguay, Brazil, and Morocco) were present too, thus achieving the EPCN's objective to better disseminate the value of the Network (Céréghino et al., 2008a; Boix et al., 2012). Still, the conference mostly attracted scientists. The content and extent of the projects led by EPCN scientists and the related oral and poster presentations (as well as recent publications), however, show that projects of EPCN members clearly include collaborations with groups of stakeholders as well as Actions aiming at influencing and informing those people who have a direct impact upon the European pond resource. Under this perspective, we claim that both the success of pond research within the framework of competitive calls for proposals and the "success stories" experienced by pond managers/ conservationist are tightly linked to the collaborative work that researchers and managers increasingly develop in practice (see examples on the EPCN website: www.europeanponds.org).

\section{Highlights}

Species-area relationships, habitat heterogeneity, and surrounding environments are well-known key drivers for local pond diversity. Jeliazkov et al. (2013) emphasize, however, that species richness significantly increases with pond density from local to regional levels. In landscapes experiencing rapid environmental changes, ponds indeed provide vital stepping stones that are essential for the migration, dispersal, and genetic exchange of wild species, including those species which range over large areas (birds and mammals) but require ponds as part of the mosaic of wetland habitats they exploit. Where pond density has declined, replacement through pond creation could also restore previously fragmented wetland landscapes (Dalbeck \& Weinberg, 2009).

While the difference between large ponds and small lakes is often debated (Oertli et al., 2005), Hamerlik et al. (2013) report an interesting ecological threshold separating alpine pond and lake systems, where, at a surface area of 2 ha, the species-area pattern changes significantly (alpha diversity was not related to area for water bodies below 2 ha, but was positively correlated with area in larger systems). The significant effects of incoming detritus and incident light upon pond community diversity, however, reveal that changes in local environments (e.g., the conversion of forest to cropping systems) strongly influence food webs in small water bodies (Dézerald et al., 2013). The set of environmental variables governing pond biodiversity (both in terms of community composition and species 
traits) is to some extent specific to climatic/biogeographic regions (Ruhí et al., 2013; de Marco et al., 2013; see also Céréghino et al., 2012) and to elevation ranges (Ilg \& Oertli, 2013). Therefore, although biological diversity could be favoured by a common set of pond management practices, data point toward the idea that management plans should include elevation- and/or region-specific measures.

Life histories, dispersal patterns, and biological interactions (notably the trophic ones) also play major roles in determining pond biodiversity (Blaustein et al., 2013). Life history patterns enable many temporally segregated populations to utilize small ecosystems by reducing competition for space and habitat resources (de Andrade et al., 2013; see also Cayrou \& Céréghino, 2005). Colonization dynamics strongly influence within and among population genetic variation and evolutionary potential of populations (Ortells et al., 2013), and more specifically, predators play a key role in generating patterns of food web topology across regional environments (Dézerald et al., 2013). Like other freshwater (and terrestrial) habitat types, ponds are subjected to species introductions (Rodriguez-Perez et al., 2013). Species richness typically decreases when fish are present (Ruggiero et al., 2008). Many fish species are predators to macroinvertebrates, while those species introduced to serve anthropogenic purposes (e.g., mosquitofish) can cause substantial injuries to large numbers of larval amphibians in a wetland (Shulse \& Semlitsch, 2013). Other introduced species like crayfish or mute swans are likely to impact either native species (e.g., amphibians) and habitat structure (e.g., macrophyte beds; Gayet et al., 2013), but the extent of adverse impacts generated by these species appears to be density-dependent.

Although ponds are small wetland features, they may be regarded as key components of wider landscapes. Compared to other surface waters, ponds still receive little effective protection from legislation or policy. More specifically, despite much interest in the management of catchments, protection of ponds through landscape scale protection measures is rarely achieved. In this context, the Important Areas for Ponds (IAP) concept proposed and developed by Pond Conservation in the UK (Pond Conservation, 2007) and the European Pond Conservation Network may serve as a relevant scheme (see an outline at http:// campus.hesge.ch/epcn/projects_propond.asp). IAPs are conceptually similar to the Important Bird Areas (IBAs proposed by Birdlife International) and the Important Plant Areas (IPAs by Plantlife International). Owing to the wide distribution of ponds, IAPs concern large areas of the landscape, thereby calling for landscape level management plans.

The ecological role and more generally the value of ponds in our landscapes are better established than a few years ago. In light of expected economic development, authoritative research-based advice is now needed to inform future direction in the conservation of small water bodies. Initiatives such as the European Pond Conservation Network play such a role by bringing together scientists, practitioners, and policy makers. To date, most ongoing projects led by EPCN members clearly aim at strengthening our understanding of pond biodiversity, ecosystem services, and the links between these two aspects. Hence, we may expect a flourish of relevant information to come and, hopefully, the 6th EPCN conference to be held in September 2014 in Huesca (Spain) should provide opportunities to learn more about pond ecology, and will certainly further contribute to bridge the gap between science and practice.

Acknowledgments The fifth conference of the European Pond Conservation Network has been made possible thanks to funding by the Fonds National de la Recherche (Luxembourg) (Convention FNR/12/AM3/15) and the Centre de Recherche Public - Gabriel Lippmann. Many thanks are due to the local organizers L. Hoffmann, C. Penny, D. Collard, C. Walczak, B. Fauvel, S. Bonot, and O. Marquis. Mr G. Schmidt is sincerely thanked for organizing the field trip in relation to the EU-LIFE Loutre project. The scientific program of the conference has been set in collaboration with Dr A. Hull (Liverpool John Moores University, UK), Dr Pascale Nicolet (Pond Conservation, UK), Dr Jeremy Biggs (Pond Conservation, UK), and Dr T. Kalettka (Centre for Agricultural Landscape research, Germany).

\section{References}

Baxter, C. V., K. D. Fausch \& W. C. Saunders, 2005. Tangled webs: reciprocal flows of invertebrate prey link streams and riparian zones. Freshwater Biology 50: 201-220.

Becerra-Jurado, G., R. Harrington \& M. Kelly-Quinn, 2012. A review of the potential of surface flow constructed wetlands to enhance macroinvertebrate diversity in agricultural landscapes with particular reference to Integrated Constructed Wetlands (ICWs). Hydrobiologia 692: 121-130.

Blaustein, J., A. Sadeh \& L. Blaustein, 2013. Influence of fire salamander larvae on among-pool distribution of mosquito 
egg rafts: oviposition habitat selection or egg raft predation? Hydrobiologia. doi:10.1007/s10750-013-1554-1.

Boix, D., J. Biggs, R. Céréghino, A. P. Hull, T. Kalettka \& B. Oertli, 2012. Pond research and management in Europe small is beautiful. Hydrobiologia 689: 1-9.

Cayrou, J. \& R. Céréghino, 2005. Life cycle phenology of some aquatic insects: implications for pond conservation. Aquatic Conservation: Marine and Freshwater Ecosystems 15: 559-571.

Céréghino, R., J. Biggs, S. Declerck \& B. Oertli, 2008a. The ecology of European ponds: defining the characteristics of a neglected freshwater habitat. Hydrobiologia 597: 1-6.

Céréghino, R., A. Ruggiero, P. Marty \& S. Angélibert, 2008b. Biodiversity and distribution patterns of freshwater invertebrates in farm ponds of a southwestern French agricultural landscape. Hydrobiologia 597: 43-51.

Céréghino, R., B. Oertli, M. Bazzanti, C. Coccia, A. Compin, J. Biggs, N. Bressi, P. Grillas, A. Hull, T. Kalettka \& O. Scher, 2012. Biological traits of European pond macroinvertebrates. Hydrobiologia 689: 51-61.

Dalbeck, L. \& K. Weinberg, 2009. Artificial ponds: a substitute for natural beaver ponds in a central European Highland (Eifel, Germany ?). Hydrobiologia 630: 49-62.

Davies, B., J. Biggs, P. Williams, M. Whitfield, P. Nicolet, D. Sear, S. Bray \& S. Maund, 2008. Comparative biodiversity of aquatic habitats in the European agricultural landscape. Agriculture, Ecosystems \& Environment 125: 1-8.

de Andrade, E. V. E., I. J. L. Palhas \& G. J. B. de Moura, 2013. Diurnal habitat segregation by tadpoles in two temporary ponds in an Atlantic Rainforest Remnant, Northeastern Brazil. Hydrobiologia. doi:10.1007/s10750013-1645-z.

de Marco, P., D. S. Nogueira, C. Costa Correa, T. Bernardi Vieira, K. Dias Silva, N. Silva Pinto, D. Bichsel, A. S. Victoriano Hirota, R. R. Silva Vieira, F. Melo Carniero, A. A. Bispo de Oliveira, P. Carvalho, R. Pereira Bastos, C. Ilg \& B. Oertli, 2013. Patterns in the organization of Cerrado pond biodiversity in Brazilian pasture landscapes. Hydrobiologia. doi:10.1007/s10750-013-1695-2.

Declerck, S., T. De Bie, D. Ercken, H. Hampel, S. Schrijvers, J. VanWichelen, V. Gillard, R. Mandiki, B. Losson, D. Bauwens, S. Keijers, W. Vyverman, B. Goddeeris, L. De Meester, L. Brendonck \& K. Martens, 2006. Ecological characteristics of small farmland ponds: associations with land use practices at multiple spatial scales. Biological Conservation 131: 523-532.

Dézerald, O., S. Talaga, C. Leroy, J. F. Carrias, B. Corbara, A. Dejean \& R. Céréghino, 2013. Environmental determinants of macroinvertebrate diversity in small water bodies: insights from tank-bromeliads. Hydrobiologia. doi:10. 1007/s10750-013-1464-2.

Downing, J. A., Y. T. Prairie, J. J. Cole, C. M. Duarte, L. J. Tranvik, R. G. Striegl, W. H. McDowell, P. Kortelainen, N. F. Caraco, J. M. Melack \& J. J. Middelburg, 2006. The global abundance and size distribution of lakes, ponds, and impoundments. Limnology and Oceanography 51: 2388-2397.

Downing, J. A., J. J. Cole, J. J. Middelburg, R. G. Striegl, C. M. Duarte, P. Kortelainen, Y. T. Prairie \& K. A. Laube, 2008. Sediment organic carbon burial in agriculturally eutrophic impoundments over the last century. Global
Biogeochemical Cycles 22: GB1018. doi:10.1029/ 2006GB002854.

EPCN, 2008. The Pond Manifesto. Available: http://campus. hesge.ch/epcn/projects.asp.

Gaston, K. J., R. M. Smith, K. Thompson \& P. H. Warren, 2005. Urban domestic gardens (II): experimental tests of methods for increasing biodiversity. Biodiversity and Conservation 14: 395-413.

Gayet, G., G. Matthieu, P. Defos du Rau \& P. Grillas, 2013. Effects of mute swans on wetlands: a synthesis. Hydrobiologia. doi:10.1007/s10750-013-1704-5.

Hamerlík, L., M. Svitok, M. Novikmec, M. Očadlík \& Peter. Bitušík, 2013. among-site and regional diversity patterns of benthic macroinvertebrates in high altitude waterbodies: do ponds differ from lakes? Hydrobiologia. doi:10.1007/ s10750-013-1621-7.

Herrmann, J., 2012. Chemical and biological benefits in a stormwater wetland in Kalmar, SE Sweden. Limnologica 42: 299-309.

Ilg, C. \& B. Oertli, 2013. How can we conserve cold stenotherm communities in warming Alpine ponds? Hydrobiologia. doi:10.1007/s10750-013-1538-1.

Jeliazkov, A., F. Chiron, J. Garnier, A. Besnard, M. Silvestre \& F. Jiguet, 2013. Level-dependence of the relationships between amphibian biodiversity and environment in pond systems within an intensive agricultural landscape. Hydrobiologia. doi:10.1007/s10750-013-1503-z.

Le Viol, I., J. Mocq, R. Julliard \& C. Kerbiriou, 2009. The contribution of motorway stormwater retention ponds to the biodiversity of aquatic macroinvertebrates. Biological Conservation 142: 3163-3171.

Mozley, A., 1944. Temporary ponds, a neglected natural resource. Nature 154: 490.

Oertli, B., J. Biggs, R. Céréghino, P. Grillas, P. Joly \& J. B. Lachavanne, 2005. Conservation and monitoring of pond biodiversity: introduction. Aquatic Conservation: Marine and Freshwater Ecosystems 15: 535-540.

Ortells, R., J. VanoVerbeke, G. Louette \& L. de Meester, 2013. Colonization of Daphnia magna in a newly created pond: founder effects and secondary immigrants. Hydrobiologia. doi:10.1007/s10750-013-1593-7.

Ott, J. A., 2001. Expansion of Mediterranean Odonata in Germany and Europe. Consequences of climatic changes. In Walther, G. R., C. A. Burga \& P. J. Edwards (eds), Fingerprints of climate change. Adapted behaviour and shifting species ranges. Kluwer Academic/Plenum Publishers, New York, Boston, Dordrecht, London, Moscow: 89-111.

Pond Conservation, 2007. A Preliminary Assessment of Important Areas for Ponds (IAPs) in Wales. Report produced for Countryside Council for Wales: $68 \mathrm{pp}$.

Quinn, P.F., J.M. Hewett, J. Jonzyk, \& V. Glenis, 2007. The PROACTIVE approach to Farm Integrated Runoff Management (FIRM) plans. Flood storage on Farms. Newcastle University. Available: http://www.ncl.ac.uk/iq/download/ PROACTIVEFloods.doc.

Rodriguez-Perez, H., H. Cayuela, S. Hilaire, A. Olivier \& F. Mesleard, 2013. Is the exotic red swamp crayfish (Procambarus clarkii) a current threat for the Mediterranean tree frog (Hyla meridionalis) in the Camargue (Southern France)? Hydrobiologia. doi:10.1007/s10750-013-1481-1. 
Rosset, V. \& B. Oertli, 2011. Freshwater biodiversity under climate warming pressure: identifying the winners and losers in temperate standing waterbodies. Biological Conservation 144: 2311-2319.

Ruggiero, A., R. Céréghino, J. Figuerola, P. Marty \& S. Angélibert, 2008. Farm ponds make a contribution to the biodiversity of aquatic insects in a French agricultural landscape. Comptes Rendus Biologies 331: 298-308.

Ruhí, A., J. Herrmann, S. Gascón, J. Sala, J. Geijer \& D. Boix, 2012. Change in biological traits and community structure of macroinvertebrates through primary succession in a man-made Swedish wetland. Freshwater Science 31: 22-37.

Ruhí, A., E. Chappuis, D. Escoriza, M. Jover, J. Sala, D. Boix, S. Gascón \& E. Gacia, 2013. Environmental filtering determines community patterns in temporary wetlands - a multi-taxon approach. Hydrobiologia. doi:10.1007/ s10750-013-1514-9.

Scher, O. \& A. Thiéry, 2005. Odonata, Amphibia and environmental characteristics in motorway stormwater retention ponds (Southern France). Hydrobiologia 551: 237251 .
Shulse, C. D. \& R. D. Semlitsch, 2013. Western Mosquitofish (Gambusia affinis) bolster the prevalence and severity of tadpole tail injuries in experimental wetlands. Hydrobiologia. doi:10.1007/s10750-013-1502-0.

Steidl, J., T. Kalettka, V. Ehlert, J. Quast \& J. Augustin, 2008. Mitigation of pressures on water bodies by nutrient retention from agricultural drainage effluents using purification ponds. Proceedings of the 10th International Drainage Workshop, Vol. 16. Helsinki University of Technology: 187-194.

Vermonden, K., R. Leuven, G. van der Velde, A. Hendriks, M. van Katwijk, J. Roelofs, E. Lucassen, O. Pedersen \& K. Sand-Jensen, 2010. Species pool versus site limitations of macrophytes in urban waters. Aquatic Sciences - Research Across Boundaries 72: 379-389.

Walther, G. R., E. Post, P. Convey, A. Menzel, C. Parmesan, T. J. C. Beebee, J. M. Fromentin, O. Hoegh-Guldberg \& F. Bairlein, 2002. Ecological responses to recent climate change. Nature 416: 389-395. 